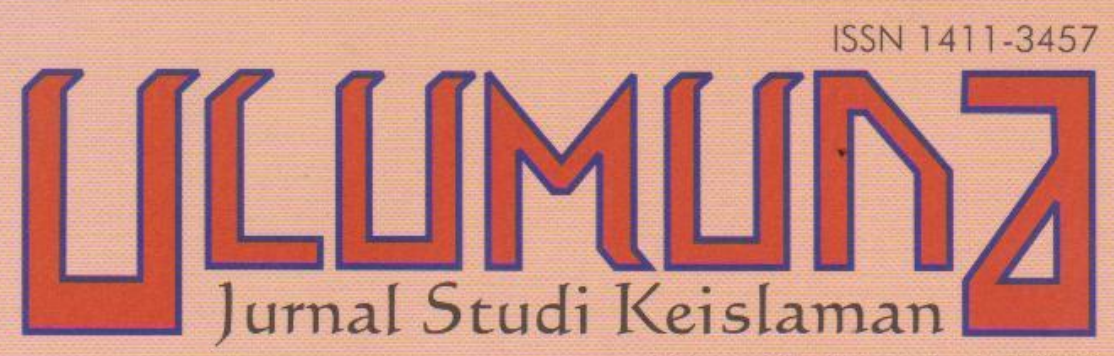

Volume XII• Nomor 1• Juni 2008

STUDI ANALITIS DIMENSI SACIFACT PENDIDIKAN ISLAM PADA MASA KEJAYAANNYA (750-1258 M) Abdul Fattah

AKTUALISASI MANUSIA VERSI AL-QUR'AN: ANTARA IDEALITAS DAN REALITAS PENDIDIKAN ISLAM Ismail Thoib

PENDIDIKAN ISLAM DAN PENCERAHAN SPIRITUALITAS: IKHTIAR MENJAWAB TANTANGAN POSMODERNISME Suparta

LESSON STUDY DALAM PEMBELAJARAN AGAMA ISLAM DI SEKOLAH UMUM Ahmad Munjin dan Khoirul Adib

STUDI PERUBAHAN KELEMBAGAAN DAN METODOLOGI PADA MADRASAH MODEL Taufik Churahman dan Musfigon POSISI PEREMPUAÑ
PERSPEKTIF ULAMA KLASIK
Baehaqi 


\section{PEDOMAN TRANSLITERASI}

\begin{tabular}{|c|c|c|c|}
\hline Arab & Latin & Arab & Latin \\
\hline 1 & $=$ & ف & $=\mathbf{f}$ \\
\hline ب & $=$ & ق & $=\mathrm{q}$ \\
\hline$\dot{H}$ & $=$ & ك & $=\mathbf{k}$ \\
\hline 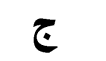 & $=$ & $J$ & $=1$ \\
\hline$\tau$ & $=$ & s & $=\mathrm{m}$ \\
\hline$\dot{\tau}$ & $=\quad \mathbf{k h}$ & $\dot{~ ن}$ & $=\mathbf{n}$ \\
\hline$د$ & $=$ & و & $=\mathbf{w}$ \\
\hline$\dot{j}$ & $d z$ & o & $=h$ \\
\hline J & $=$ & $\varepsilon$ & $=$, \\
\hline j & $=$ & 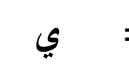 & $=y$ \\
\hline س - س & $=$ & & \\
\hline ش & $=$ & \multirow{2}{*}{\multicolumn{2}{|c|}{$\begin{array}{l}\text { Untuk Madd } \\
\text { dan Diftong }\end{array}$}} \\
\hline ص & sh & & \\
\hline ض & dl & i & $=$ â (a panjang) \\
\hline b & th & = & $=\hat{\mathbf{i}}(\mathbf{i}$ panjang) \\
\hline ظ & $\mathbf{z h}$ & أوز & $=\quad \hat{\mathbf{u}}$ (u panjang) \\
\hline$\varepsilon$ & $=$ & آون & $=\mathbf{a w}$ \\
\hline$\dot{\varepsilon}$ & $=\mathrm{gh}$ & = & $=a y$ \\
\hline
\end{tabular}




\section{ISI}

TRANSLITERASI

ANTARAN

UTAMA

Abdul Fattah

Studi Analitis Dimensi Sacifact Pendidikan Islam pada Masa Kejayaannya $(750-1258 \mathrm{M}) \bullet 1-28$

Ismail Thoib

Aktualisasi Manusia Versi Al-Qur'an:

Antara Idealitas dan Realitas

Pendidikan Islam • 29-46

Suparta

Pendidikan Islam dan Pencerahan

Spiritualitas: Ikhtiar Menjawab Tantangan

Posmodernisme • 47-66

Ahmad Munjin Nasih Lesson Study dalam Pembelajaran

dan Khoirul Adib Pendidikan Agama Islam

di Sekolah Umum • 67-88

Taufik Churahman Dinamika Pendidikan Islam: Studi

dan Musfiqon

Perubahan Kelembagaan dan Metodologi

pada Madrasah Model • 89-106

LEPAS

Mutawalli Pembaruan Hukum Islam:

Menimbang Tawaran Pemikiran

'Abd al-Lâh al-Na'îm • 107-128

Baehaqi Posisi Perempuan

Perspektif Ulama Klasik • 129-142

Ahmad Sulhan Islam Kontemporer: Antara Reformasi

dan Revolusi Peradaban • 143-156

Ahmad Choirul Rofiq Menilai Kompetensi al-Mâturîdî di Bidang

Tafsir al-Qur'an • 157-182

ULAS BUKU

Yayuk Fauziyah Menyingkap Kuasa Maskulinitas di Balik

Tabir Feminitas Wanita Jawa • 183-200

INDEKS 


\title{
PENDIDIKAN ISLAM DAN PENCERAHAN \\ SPIRITUALITAS: IKHTIAR MENJAWAB \\ TANTANGAN POSMODERNISME
}

\author{
Suparta*
}

\begin{abstract}
This article elaborates modern phenomena that come into human's life with their ambiguous face. On one hand, modernity gives human material and biological satisfaction resulted from advances in science and technology. On the other hand, it leads people to the meaningless life, existentially and spiritually. In the post-modern era, Islamic education is aimed to give alternative solutions which can change human life paradigm from material orientation into spiritual orientation because the Islamic education value can be seen from its contents including maintenance of human life development in all aspects, materially, spiritually, intellectually, socially and experimentally. This article emphasizes that Islamic education does not only justify aqly and naqly knowledge development, but also synthesizes the two into one scientific paradigm.
\end{abstract}

Keywords: Pendidikan Islam, Posmodernisme, Dunia Spiritual, Paradigma Alternatif, Sains dan Teknologi, Ilmu-ilmu Agama.

SECARA teoritis, Islam merupakan "manhaj rabbânî" yang sempurna yang selalu memupuk sekaligus mengembangkan fitrah manusia sehingga ia menjadi sosok pribadi muslim yang sempurna yang selalu berubah serta beradaptasi dengan kemajuan zaman. Artinya, pendidikan Islam dalam hal ini dapat

*Penulis adalah dosen Sekolah Tinggi Ilmu Agama Islam Negeri (STAIN) Saikh Abdurrahman Siddik Kepulauan Bangka Belitung. email: sparta_stainsas@yahoo.co.id 
membentuk pribadi seseorang menjadi pribadi muslim yang tidak hanya anggun secara moral-spiritual, namun juga tangguh secara intelektual.

Syed Sajjad Husain dan Syed Ali Ashraf ${ }^{1}$ mengatakan bahwa pendidikan Islam secara idealis merupakan suatu pendidikan yang melatih perasaan murid-murid sehingga segala aktivitasnya baik itu sikap hidup, tindakan, keputusan, serta pendekatan mereka terhadap segala jenis ilmu pengetahuan selalu berdasarkan nilai-nilai spiritual dan sangat sadar dengan nilai etis Islam. Dengan kata lain, pendidikan Islam selalu mengantarkan manusia pada perilaku dan perbuatan manusia yang berpedoman pada syari'at Allah. ${ }^{2}$ Sehingga, pendidikan Islam bukanlah pendidikan yang hanya sekedar "transfer of knowledge" atau "transfer of training", tetapi lebih merupakan suatu sistem yang terkait secara langsung dengan Tuhan. ${ }^{3}$

Berdasarkan konsepsi di atas, dapat ditegaskan bahwa pendidikan Islam merupakan suatu sistem atau metode untuk meningkatkan kualitas hidup manusia dalam segala aspek kehidupan, baik secara moral spiritual maupun secara material dan intelektual. Dalam hal ini yang perlu digarisbawahi bahwa pendidikan Islam lebih menitikberatkan pada peningkatan moral spiritual sebagai alat kontrol bagi aspek yang lainnya, yaitu sebagai pengontrol kecenderungan material dan daya intelektual liar yang dimiliki. Dihajatkan melalui kepemilikan aspek moral spiritual yang baik, otomatis ia akan menggunakan serta memanfaatkan kekayaan material dan daya intelektualnya dengan baik pula. Sementara tanpa adanya moral spiritual yang baik (baca: sebagai pengontrol), maka ia akan menggunakan kekayaan

'Syed Sajjad Husain dan Syed Ali Ashraf, Krisis Pendidikan Islam, ter. Rahmani Astuti (Bandung: Risalah, 1986), 2.

2Abdurrahman An-Nahlawy, Pendidikan Islam di Rumah, Sekolah, dan Masyarakat, ter. Shihabuddin (Jakarta: Gema Insani Press, 1995), 26.

${ }^{3}$ Roehan Anwar, "Prinsip-prinsip Pendidikan Islam Versi Mursi", dalam Jurnal Pendidikan Islam IAIN Sunan Kalijaga, vol. 1, Yogyakarta, 1991, 50. 
material dan daya intelektualnya tersebut ke jalan kesesatan yang dapat merugikan manusia yang lain.

Pada faktanya, untuk merealisasikan harapan atau tujuan pendidikan Islam tersebut ternyata tidak semudah membalikkan telapak tangan. Hal ini dapat dilihat pada fenomena yang ada, yakni selalu terjadi kontradiksi antara cita dan fakta. Semua itu tentunya menjadi tanggung jawab bersama seluruh komponen, terutama pihak pemerintah dan para pakar pendidikan Islam dalam menghadapi fenomena akut yang sudah berada pada tingkat yang sangat mengkhawatirkan tersebut.

Memang benar, fenomena tersebut telah menimbulkan rasa kekhawatiran maupun kegelisahan pada setiap komponen masyarakat, terlebih lagi bagi para pakar/pemerhati dunia pendidikan Islam. Kenyataan tersebut diperparah lagi bahwa pendidikan Islam saat ini dihadapkan pada tantangan kehidupan manusia modern. Dengan demikian, pendidikan Islam harus diarahkan pada kebutuhan perubahan masyarakat modern. Untuk menyikapi perubahan-perubahan tersebut diperlukan suatu desain paradigma baru bagi pendidikan Islam di dalam menghadapi tuntutan-tuntutan yang baru.

Menurut Kuhn, ${ }^{4}$ apabila tantangan-tantangan baru itu dihadapi dengan menggunakan paradigma lama maka segala usaha yang dijalankan akan menemui kegagalan. Begitu juga halnya dengan pendidikan Islam apabila ingin mendapatkan keberhasilan otomatis harus didesain ulang supaya dapat menjawab perubahan serta tantangan saat ini. Perubahan yang sedang terjadi saat ini adalah perubahan orientasi manusia modern dari yang berorientasi material kepada spiritual. Maksudnya, manusia modern saat ini sudah jenuh dengan kehidupannya yang serba ada dalam bidang material akan tetapi merasa kosong atau hampa di bidang spiritual.

${ }^{4}$ H. A. R. Tilaar, Beberapa Agenda Reformasi Pendidikan dalam Perspektif Abad 21 (Magelang: Tera Indonesia, 1998), 103. 
Dalam situasi dan kondisi seperti ini, di mana manusia modern telah mencapai puncak "orgasme" di berbagai aspek kehidupan khususnya dan di bidang pemenuhan kebutuhan secara biologis-material, sementara ketentraman dan kedamaian batiniah belum tercukupi. Maka sudah saatnya pendidikan Islam mampu menawarkan solusi alternatif atau paling tidak menawarkan "panacea" kepada mereka. Ini paling tidak dilakukan dengan cara mengawinkan antara pendidikan Islam dengan spiritualitas. Dalam artikel ini, penulis akan berusaha memberikan jawaban terhadap sejumlah pertanyaan mendasar; apakah benar kebangkitan spiritual akan terjadi di era posmodern? Apakah benar spiritualitas sudah menjadi kebutuhan pokok bagi manusia modern? Bagaimanakah paradigma pendidikan Islam dalam mengatasi problem spiritualitas? Dan bagaimanakah implikasi-implikasi hal tersebut bagi dunia pendidikan?

\section{Posmodernisme: Awal Kebangkitan Spiritualitas}

Realitas kekinian menunjukkan bahwa gejala posmodernisme demikian cepat merambah pada semua bidang persoalan termasuk keagamaan. Sesuai dengan watak epistemologis posmodernisme yang ingin menghidupkan berbagai macam narasi yang ada, maka agama dalam perspektif posmodern dicoba diangkat baik dalam kecenderungan sejarah (trend of history) kontemporer, maupun sebagai bagian dari legitimasi epistemologis dalam mencari kebenaran setelah sekian lama menjadi kebenaran yang terlupakan (forgotten truth) dalam paradigma pemikiran modern. ${ }^{5}$

Untuk itu, sebagai kecenderungan sejarah, posmodern menggambarkan adanya krisis spiritual yang akan dihadapi oleh manusia modern. Hal tersebut menjelaskan bahwa ada dimensi

${ }^{5}$ Syamsul Arifin, Spiritualisasi Islam dan Peradaban Masa Depan (Yogyakarta: SIPRES, 1996), 34. 
lain yang terlupakan oleh manusia modern selama ini yaitu dimensi ilahiyah. Agar dapat keluar dari krisis tersebut maka manusia modern diniscayakan kembali pada hikmah spiritual yang terdapat dalam agama yang selama ini sudah terlupakan.

Saat ini indikasi ke arah kebutuhan manusia modern terhadap spiritual sudah mulai nampak. Di Barat misalnya, hal tersebut ditandai dengan maraknya fundamentalisme agama (religious fundamentalism) yang menimbulkan ketakutan luar biasa bagi kalangan tertentu. Sementara di kalangan umat Islam ditandai dengan berbagai artikulasi keagamaan seperti kelompok revivalis-fundamentalis, kelompok modernisme dengan berbagai improvisasinya, sampai pada bentuk artikulasi yang esoterik seperti yang nampak pada gerakan sufisme yang juga tengah menggejala akhir-akhir ini. ${ }^{6}$

Adanya kecenderungan manusia modern terhadap dunia spiritual karena kehidupan modern sekarang ini tampil dengan wajah antagonistik. Di satu pihak, modernisasi telah mendatangkan berbagai macam kemajuan yang spektakuler dalam bidang material. Namun di pihak lain, modernisasi menghasilkan wajah kemanusiaan yang buram, seperti terlihat pada aspek negatif yang ditimbulkannya. Dampak negatifnya misalnya, manusia modern akhirnya makin terasing dari diri dan Tuhannya. Akibat dari keterasingan itu, akhirnya manusia modern tidak menemukan kebahagiaan dan ketentraman dalam hidupnya. Justru sebaliknya yang mereka temukan hanyalah kegelisahan dan kegersangan baik secara psikologis maupun secara spiritualis sehingga mereka merasa bingung dalam menentukan tujuan dan makna hidupnya.

Di dunia Barat, kecenderungan untuk kembali pada dunia spiritual ditandai dengan semakin merebaknya gerakan fundamentalisme agama dan kerohanian. Munculnya fenomena

'Untuk lebih jelasnya dapat dilihat pada Akbar S. Ahmed, Postmodernisme and Islam, ter. Muhammad Siroji (Bandung: Mizan, Bandung, 1997), 25-100. 
ini cukup menarik dicermati karena polanya jauh berbeda dengan agama-agama formal. Naisbitt menyatakan, mereka bukan manusia beragama melainkan kerohanian. Perkembangan ini tidak dapat dilepaskan dari akibat-akibat kemanusiaan yang muncul dalam proses modernisasi yang kemudian mendorongnya mencari tempat pelarian yang memberikan perlindungan dan kepuasan dengan cepat. Hal ini dapat diperoleh dengan cara memasuki gerakan fundamentalisme dan kerohanian. ${ }^{7}$

Tetapi perkembangan spiritualisme dalam bentuk gerakan fundamentalisme ini banyak menimbulkan persoalan psikologis dan sosiologis. Fundamentalisme agama dengan bentuk-bentuk pengutusan yang berada di dalamnya hanya menawarkan janjijanji keselamatan yang absurd dan ketenangan batin yang sifatnya sementara (palliative). Lebih parahnya lagi, fundamentalisme agama ternyata melahirkan bentuk otoritarianisme baru yang memakai legitimasi agama. Hal ini menurut Erich Fromm disebut dengan agama autoritarian (authoritarianisme religion) sebagai kebalikan dari agama humanistik (bumanistic religion). ${ }^{8}$ Dengan demikian, model spiritualisme yang seperti ini bukanlah mendapatkan kebebasan dan kepuasan tetapi justru sebaliknya.

\section{Spiritualitas: Kebutuhan Pokok Manusia Modern}

Hal yang menarik terkait perbincangan manusia modern adalah ketertarikannya terhadap dunia spiritual. Ketertarikannya itu pada dasarnya ingin mencari keseimbangan baru dalam hidupnya. Dalam pandangan yang agak eksistensialis ingin kembali kepada kemerdekaan manusia yang telah mengalami

${ }^{7}$ Raymond Toruan, Globalisasi: Dunia Makin Panas dalam Menuju Masyarakat Baru Indonesia, Antisipasi terhadap Tantangan Abad XXI (Jakarta: Gramedia, 1990), 53.

${ }^{8}$ Lihat Yaya M. Abdul Aziz (ed.), Visi Global: Antisipasi Indonesia Memasuki Abad ke XXI (Yogyakarta: Pustaka Pelajar, 1998), 19-53. 
reduksionisasi dalam kehidupan modern. Harapan hidup tersebut dapat tercapai apabila manusia modern tersebut dapat hidup dengan cara melakukan transendensi terus menerus. Dalam proses transendensi ini kemudian tidak hanya berhenti pada realitas yang profan dalam konteks ruang dan waktu yang amat terbatas, tetapi ditransendensikan kepada realitas yang mutlak atau absolut (ultimate reality). Sebab, keseimbangan hidup yang sempurna serta kebebasan dan kepuasan hidup yang hakiki terletak dalam proses transendensi tersebut.?

Menurut Syamsul Arifin, ${ }^{10}$ hidup dengan visi dan artikulasi seperti di atas sesungguhnya lebih merupakan persoalan yang bersifat paradigmatis. Artinya, bagaimana hidup ini dimaknai sangat tergantung pada paradigma hidup yang dipandang. Sementara bagi orang modern paradigma yang dipakai adalah dibangun atas premis-premis rasionalisme, empirisme, dan positivisme. Dengan demikian, paradigma tersebut tidak akan mampu menyingkap kesemestaan kehidupan karena sejak awal telah menolak atau mendekonstruksi realitas yang berada di luar jangkauan indera dan rasio manusia. Paradigma ini otomatis memiliki konfrontasi yang signifikan dengan paradigma orangorang yang beriman yang berkeyakinan bahwa realitas inderawi merupakan derivasi dari realitas yang lebih tinggi.

Pergeseran paradigma (shifting paradigm) rupanya sudah menjadi keharusan bagi manusia modern agar kembali kepada hakikat kehidupan. Untuk itu, spiritual rupanya dijadikan sebagai alternatif paradigma, paling tidak menjadi diskursus yang hangat,

${ }^{9}$ Dalam Islam keseimbangan ini adalah kesimbangan antara kehidupan di dunia dan di akhirat. Dengan kata lain, umat Islam dianjurkan mencari kebahagiaan dan kesejahteraan baik di dunia maupun di akhirat. Hal ini sesuai dengan firman Allah dalam Qs. al-Baqârah (2): 201 yang artinya: "Ya Tuban kami anugerabkanlah kepada kami kebaikan di dunia, juga kebaikan di akbirat serta jaubleanlah kami dari siksa api neraka".

${ }^{10}$ Lihat Syamsul Arifin, Spiritualisasi Islam dan Peradaban Masa Depan (Yogyakarta: SIPRESS, 1996), 37-8. 
di mana spiritual dipandang sebagai bagian yang signifikan dan fungsional bagi sejarah kemanusiaan masa depan. Namun demikian, di balik jubah optimisme tersebut terkait masa depan spiritual terdapat pertanyaan yang mendasar tentang model spiritual yang akan terjadi dan yang mampu menyangga kebutuhan spiritualitas manusia masa depan. Hal ini seperti yang dikatakan oleh Erich Fromm dalam bukunya, "religion and psychoanalisys", bukan beragama apa, tapi beragama yang bagaimana.

Supaya manusia modern tidak terjebak pada pemahaman agama yang hanya bersifat eksoteris yakni sebuah pemahaman agama yang hanya bersifat simbolik dan formalistik yang akhirnya mengakibatkan pemenuhan kepuasan psikologis dan sosiologis yang absurd, maka hendaknya pemahaman agama yang bersifat esoteris tidak mesti ditinggalkan. Sebab bila berada dalam bingkai yang seimbang antara dimensi eksoteris dan esoteris, maka akan mengantarkan seseorang pada ekstase keberagamaan yang menyejukkan dan memberikan kedamaian yang luar biasa. Karena realitas dimensi esoteris tidak berhenti dan terbatas pada aktivitas keagamaan yang formal dan simbolik, maka efek dari pemahaman esoteris ini akan muncul menjadi sikap hidup yang signifikan dan fungsional bagi alam sekitar.

\section{Pendidikan Islam Menjawab Problem Spiritualitas}

Tidak ada yang paling mengkhawatirkan pada kehidupan dunia mutakhir ini kecuali kehancuran moral spiritual dan kehancuran rasa perikemanusiaan antara manusia. Manusia telah dikuasai oleh berbagai kepentingan dunia dan telah dibebani oleh berbagai kemewahan dunia. Lebih parah lagi, manusia modern justru telah menuhankan dunia. Hal ini dapat disaksikan pada dataran realitas pesatnya kemajuan sains dan teknologi yang telah menyebabkan kemajuan dan kemakmuran kesejahteraan hidup manusia di satu sisi. Namun, di sisi lain pesatnya sains dan 
teknologi (tanpa disertai iman) telah menyeret manusia pada kegersangan dan kebutaan dimensi-dimensi spiritual.

Oleh sebab itu, makna hidup tidak lagi dimaknai sebagai manifestasi pengabdian suci untuk menata kehidupan berkebudayaan secara harmonis melainkan telah mengukuhkan suatu tatanan hukum rimba yang sangat meracuni budayabudaya yang berwawasan kemanusiaan. Citra manusia pun bergeser dari konsep sifat manusia yang hakiki yaitu manusia yang baik dan bajik adalah yang kuat. Hal itu berubah menjadi sebaliknya, yaitu manusia yang curang dan jahatlah yang akan menguasai tatanan kemanusiaan sehingga manusia terjebak pada kenyataan yang menyesatkan yakni berusaha "rebutan ladang" kepentingan masing-masing dengan berbagai tipu muslihat.

Di balik realitas sosial yang demikian, pendidikan pun sudah mulai diorientasikan pada posisi yang tidak jauh dari mainstream perkembangan sains dan teknologi modern, yang secara akademis akan dijadikan aset kemodernan dengan mengenyampingkan aspek spiritual dalam pendidikan. Jika yang terjadi demikian, otomatis yang tercetak adalah manusia-manusia yang unggul secara intelektual, tetapi justru gersang secara moral-spiritual. Padahal, yang diharapkan adalah proses dan realitas pendidikan yang dapat mencetak manusia yang anggun secara moral-spiritual dan tangguh secara intelektual.

Pergeseran-pergesaran paradigma manusia modern yang salah seperti yang telah dijelaskan di atas, nampaknya akan menjadi konsekuensi logis dari kecenderungan-kecenderungan yang ada saat ini dan landasan-landasan yang dipakainya. Hal ini sesuai yang dikatakan oleh Cyril Edwin Black dalam bukunya yang berjudul "Changes as Condition of Modern Life" abad mutakhir ini berdaya kuat merombak struktur nilai-nilai (social values) yang akhirnya memberi peluang akan hadirnya nilai-nilai baru, pilihanpilihan baru, dan pandangan-pandangan baru yang kemudian 
mengkristal dalam pranata budaya yang cenderung tidak manusiawi. ${ }^{11}$

Kristalisasi budaya tersebut sangat melekat dengan perkembangan ilmu pengetahuan dan teknologi yang ditransformasikan melalui proses pendidikan yang berwawasan parsial dan tidak lagi berpijak pada nilai-nilai normatif ilahiyah. Sehingga, munculah konsekuensi-konsekuensi baru sebagai problematika kemanusiaan. Problem yang paling penting dalam hal ini adalah problematika manusia dalam pemenuhan kebutuhan di bidang spiritual.

Dalam transformasi nilai yang amat krusial itu, orientasi pendidikan memegang peranan penting sebagai suatu harapan dalam meluruskan penyimpangan-penyimpangan yang terjadi baik dalam pranata moral maupun dalam pranata sosial, personal atau individual yang berkenaan dengan persepsi ilmu dan implementasinya dalam kehidupan praktis manusia. Namun, lagi-lagi akhirnya manusia dihadapkan pada pilihan-pilihan yang akan membingungkan, yaitu konsep pendidikan yang mana dan bagaimana yang akan memberi gambaran orientasi yang utuh sebagai solusi alternatif dalam upaya "memanusiakan manusia" dengan menekankan pada perpaduan antara iptek dan imtak. Kondisi akhir yang hendak tercipta adalah terwujudnya harmonisasi hubungan, baik dengan sesama dan lingkungan (horizontal) maupun hubungan manusia dengan ilahinya (vertikal).

Dalam bingkai pemahaman ini, Fachry Ali mengingatkan:

${ }^{11}$ Maksud dari tidak manusiawi di sini adalah keadaan zaman modern di mana manusia terlalu dikuasai oleh sains dan teknologi sehingga lebih disibukkan oleh keduniaannya daripada memikirkan kemanusiaannya. Manusia lebih senang mencari dan membantu orang lain selagi sesuai dengan kepentingannya, bahkan orang modern pun tak akan segan-segan membunuh dan menghancurkan kehidupan manusia yang lainnya selagi masih bersangkutan dengan kepentingannya. Sifat semacam itu menurut kacamata Islam, lebih bejat daripada hewan. 
"Pendidikan yang didasarkan atas tuntutan ilmu pengetahuan dan kebutuhan teknik ialah pendidikan yang mengutamakan perkembangan ratio semata. Pendidikan yang demikian akan menghasilkan orang-orang cerdik pandai yang mempunyai pikiran brilian, akan tetapi dalam pandangan jagadnya (world view) mempunyai asas-asas pikiran yang salah. Pikiran yang salah dan falsafah yang salah walaupun sangat kecil akan menimbulkan kerusakan dan kelumpuhan di dalam organisasi kosmos, seluruh masyarakat dan di dalam tatanan politik suatu negara". ${ }^{12}$

Seide dengan pemikiran di atas, Karl Jaspers lebih khawatir lagi dalam memasuki dunia mutakhir ini seraya mengungkapkan:

"Dunia saat ini benar-benar mengalami despiritulisasi yang tunduk pada regim kemajuan teknologi (de spiritualization of the world and its subjection to a regime of advance tenique)".13

Semua itu disinyalir terjadi karena miskinnya manusia dari wawasan spiritual-etik pada seluruh dimensi keilmuan yang dikembangkan selama ini.

Pengembangan spiritualitas manusia menjadi sesuatu yang asing dalam proses pendidikan modern. Dengan kata lain, paradigma sistem pendidikan yang dikembangkan sejalan dengan perkembangan paradigma ilmu pengetahuan kontemporer (modern) dengan kadar rasionalisme dan empirisme yang tinggi dalam upaya mentransfer ilmu-ilmu objektif. Akhirnya, pendidikan bergeser ke arah sains dan teknologi semata tanpa menghiraukan aspek spiritual. Padahal, antara ilmu empirik dan metafisik, antara akal dan wahyu, antara ilmu umum dan agama, idealnya berpadu. Dengan kata lain, tidak boleh dipisah-pisahkan antara lapangan berpikir empirik dengan lapangan idealnormatif. Lebih jelasnya, konseptualisasi ilmu pengetahuan

${ }^{12}$ Lihat Fachry Ali, Agama, Islam dan Pembangunan (Yogyakarta: PLP2M,1985), 56-79 dan Islam, Ideologi Dunia, dan Dominasi Struktural (Bandung: Mizan, 1985), 34.

${ }^{13}$ Ibid. 
dalam pendidikan harus menawarkan adanya "ilmu naqliyah" yang dapat melandasi semua "ilmu aqliyah".

Harapan yang kerap tercuat adalah semakin banyak ilmu pengetahuan dan teknologi serta peradaban yang gemilang meniscayakan manusia semakin arif dalam mengarungi kehidupannya. Namun yang terjadi justru sebaliknya. Semakin banyak perubahan dan peradaban yang diraih, justru menjadikan manusia semakin tak terkendali. Karenanya, secara ekstrim Ziauddin Sardar menyatakan bahwa zaman modern ternyata sama sekali bukan rahmat. ${ }^{14}$ Pendapat Sardar tersebut tampaknya didasarkan pada fakta yang ada saat ini di mana manusia di samping memiliki potensi perubahan peradaban yang cepat, pada saat yang sama mengalami degradasi moral yang cepat pula.

Keprihatinan dan kehawatiran dalam menghadapi zaman modern ini diungkapkan juga oleh Fromm bukan sebagai ancaman terhadap satu kelas atau satu bangsa tetapi merupakan ancaman bagi semua. ${ }^{15}$ Dengan demikian, ternyata dampak dari kemajuan masyarakat modern saat ini bukan hanya berdampak positif saja akan tetapi berdampak negatif pula. Salah satu dampak negatifnya adalah manusia tidak lagi merasakan dirinya sebagai pembawa aktif dari kekuatan dan kekayaannya, tetapi sebagai benda yang dimiskinkan, yakni benda yang tergantung kepada kekuatan di luar dirinya, kepada siapa ia telah memproyeksikan substansi hayati dirinya. ${ }^{16}$

${ }^{14}$ Lihat A. Malik Fadjar, "Menyiasati Kebutuhan Masyarakat Modern Terhadap Pendidikan Luar Sekolah", makalah disampaikan dalam Seminar dan Lokakarya Pengembangan Pendidikan Islam Menyongsong Abad 21, IAIN Cirebon, tanggal 31 Agustus s/d 1 Sepetember, 1995, 1-10.

${ }^{15}$ Lihat Ahmad Syafi'i Ma'arif, "Pemikiran tentang Pembaharuan Pendidikan Islam di Indonesia", dalam Muslih Usa (ed.), Pendidikan Islam antara Cita dan Fakta (Yogyakarta: Tiara Wacana, 1991), 22-52.

${ }^{16}$ Fadjar, "Menyiasati...., 20. 
Semua persoalan fundamental yang dihadapi oleh masyarakat modern yang telah diilustrasikan di atas, menjadi pemicu munculnya kesadaran epistemologis baru bahwa persoalan kemanusiaan tidak cukup diselesaikan dengan cara penekanan aspek empirik-rasional tetapi perlu jawaban yang transendental. ${ }^{17}$

Dalam kancah persoalan krusial tersebut, sesungguhnya pendidikan Islam memiliki peluang besar untuk menjadi "entitas solutif" di mana pendidikan Islam penuh dengan muatanmuatan spiritual yang relevan untuk menjawab tantangan perubahan tersebut. Pada kenyataannya, pendidikan Islam lebih mengedepankan aspek spiritual, sementara pendidikan sekular lebih mengedepankan aspek materialnya. Demikianlah, agama akhirnya dipandang sebagai alternatif paradigma yang dapat memberikan solusi secara mendasar terhadap persoalan kemanusiaan yang sedang dihadapi oleh masyarakat modern.

Dalam hal ini, pendidikan Islam dihajatkan mampu mengadakan perubahan sekaligus sebagai salah satu entitas yang dapat dijadikan solusi alternatif untuk menjawab tantangan dan perubahan zaman. Sebab, nilai pluas pendidikan Islam dapat dilihat dari kandungannya yang meliputi pemeliharaan seluruh aspek perkembangan; baik material, spiritual, intelektual, perilaku sosial, apresiasi, atau pengalaman. ${ }^{18}$ Dengan demikian, idealnya melalui pendidikan Islam ini masyarakat tidak lagi terjebak pada kesenangan yang nisbi akan tetapi selalu mencari kesenangan yang hakiki yaitu "menghambakan" dirinya hanya semata-mata kepada Tuhan.

Dalam kerangka terjadinya sinergitas antara sains dan teknologi dengan ilmu-ilmu agama, maka pendidikan masa depan yang dikemas harus kembali kepada desain tujuan awal pendidikan Islam itu sendiri yaitu: pertama, pendidikan dalam konsepsi ajaran Islam merupakan manifestasi dari tugas

${ }^{17}$ Ibid, 4.

${ }^{18}$ An-Nahlawy, Pendidikan..., 253. 
kekhalifahan umat manusia di muka bumi ini. Manifestasi ini akan bermakna fungsional apabila seluruh fenomena kehidupan yang muncul dapat diberi batasan-batasan nilai moralitasnya, sehingga tugas kekhalifahan itu tidak justru berada di luar koridor nilai-nilai itu. Konsekuensinya, tujuan transendental tersebut mengisyaratkan kepada manusia agar dalam proses pendidikannya selalu cendrung pada ajaran-ajaran pokok dari sang pendidik yang paling utama dan pertama, yakni sebagai Rabb al-'Alamîn dan sekaligus sebagai Rabb al-Nâs. Kedua, bahwa kesatuan alam dan manusia sebagai totalitas ciptaan Allah di mana manusia diberi otoritas relatif untuk mendayagunakan alam maka tidak bisa terlepas dari sifat al-Raḅmân dan al-Rahîm Allah. Oleh karena itu, pendidikan sebagai bagian pokok dari aktivitas pembinaan kehidupan manusia harus mampu mengembangkan rasa kepatuhan dan rasa syukur yang mendalam kepada Tuhan sehingga beban tanggung jawab manusia tidak ditujukan pada selain Allah. Inilah sebenarnya makna tauhid yang mendasari segala aspek pendidikan Islam. Ketiga, atas dasar makna tauhid tersebut, pendidikan Islam mendasarkan orientasinya pada upaya menyucikan diri dan memberikan penerangan jiwa sehingga setiap diri manusia mampu meningkatkan dirinya dari tingkatan iman ke tingkatan ihsan yang melandasi seluruh bentuk aktivitas kesehariannya.

Untuk lebih jelasnya di bawah ini akan dibuat desain perubahan paradigma ilmu pengetahuan kontemporer di masa yang akan datang; ilmu pengetahuan kontemporer seharusnya diwarnai dengan nuansa spiritual yang kental sehingga semakin pandai seseorang maka akan semakin tunduk pula pada Tuhan dalam arti sesungguhnya. Adapun perubahan yang diharapkan adalah tergambar dalam skema berikut: ${ }^{19}$

19Dapat dilihat pada dua tulisan Hidayat Nata Atmaja, Karsa Menegakean Jiwa Agama dalam Dunia Ilmiah versi Ibya Ulumuddin (Bandung: Iqra', 2000), 27-57 dan Krisis Global Ilmu Pengetabuan dan Penyembubannya, seri Psy-War no. 001/82 (Bandung: Iqra', 1982), 42-3. 


\begin{tabular}{|c|c|}
\hline $\begin{array}{l}\text { LMU PENGETAHUAN } \\
\text { KONTEMPORER }\end{array}$ & $\begin{array}{c}\text { ILMU PENGETAHUAN } \\
\text { ALTERNATIF MASA DEPAN }\end{array}$ \\
\hline - Rasion & $\begin{array}{l}\text { - Rasionalisme yang berpijak pada } \\
\text { dasar intuisi, pengenalan langsung } \\
\text { spiritual. }\end{array}$ \\
\hline - Empirisme murni. & $\begin{array}{l}\text { - Empirisme yang berpijak pada } \\
\text { dasar meta-empiris atau keghaiban. }\end{array}$ \\
\hline - Sains dimulai dari ragu. & $\begin{array}{l}\text { - Sains mulai dari keyakinan } \\
\text { agamawi. }\end{array}$ \\
\hline $\begin{array}{l}\text { - Agnostik terhadap segala } \\
\text { sesuatu yang ghaib. }\end{array}$ & $\begin{array}{l}\text { - Beriman dan secara eksplisit } \\
\text { mengungkapkan hubungan antara } \\
\text { yang ghaib dengan yang empiris. }\end{array}$ \\
\hline $\begin{array}{l}\text { - Sains mulai dari model parsial } \\
\text { dan melangkah ke pengenalan } \\
\text { holistik. }\end{array}$ & $\begin{array}{l}\text { - Sains mulai dari pengenalan holistik } \\
\text { agamawi baru melangkah ke } \\
\text { spesialisasi atau model parsial. }\end{array}$ \\
\hline $\begin{array}{l}\text { - Kebenaran sains independen } \\
\text { terhadap kebenaran agama. }\end{array}$ & $\begin{array}{l}\text { - Sains hanya bisa bicara mengenai } \\
\text { kebetulan, karena kebenaran } \\
\text { absolut hanya bisa dijangkau oleh } \\
\text { penghayatan agamawi. }\end{array}$ \\
\hline $\begin{array}{l}\text { - Sains dipandang murni sebagai } \\
\text { kreasi manusia. }\end{array}$ & $\begin{array}{l}\text { - Mustahil tanpa adanya karunia dan } \\
\text { bimbingan Allah manusia bisa } \\
\text { berkreasi. }\end{array}$ \\
\hline $\begin{array}{l}\text { - Sains netral terhadap nilai, } \\
\text { moral, agama dan ideologi. }\end{array}$ & $\begin{array}{l}\text { - Sains berpijak pada dasar agamawi } \\
\text { yang dalam kehidupan sosial multi } \\
\text { "agama" dituangkan dalam bentuk } \\
\text { konsensus ideologi. }\end{array}$ \\
\hline $\begin{array}{l}\text { - Manusia adalah binatang } \\
\text { berakal. }\end{array}$ & $\begin{array}{l}\text { - Manusia adalah makhluk material } \\
\text { dan spiritual yang memiliki } \\
\text { kesadaran mandiri dan kesadaran } \\
\text { spiritual agamawi. }\end{array}$ \\
\hline $\begin{array}{l}\text { - Sesuatu yang gaib itu } \\
\text { mengandung arti abstrak- } \\
\text { spekulatif. }\end{array}$ & $\begin{array}{l}\text { - Kegaiban yang hak justru memiliki } \\
\text { keabsahan yang lebih tinggi dari } \\
\text { pada kesemuaan dunia empiris, } \\
\text { karena itu memiliki ciri kepastian di } \\
\text { alam nyata eksperimental. }\end{array}$ \\
\hline $\begin{array}{l}\text { - Tak ada kesatuan ontologis } \\
\text { antara realitas fisis dan } \\
\text { metafisis. }\end{array}$ & $\begin{array}{l}\text { - Terdapat kesatuan ontologis antara } \\
\text { realitas fisis dan metafisis yang } \\
\text { diturunkan dari prinsip ketunggalan } \\
\text { pencipta (prinsip-prinsip tauhid). }\end{array}$ \\
\hline
\end{tabular}




\begin{tabular}{|c|c|}
\hline $\begin{array}{l}\text { LMU PENGETAHUAN } \\
\text { KONTEMPORER } \\
\end{array}$ & $\begin{array}{c}\text { ILMU PENGETAHUAN } \\
\text { ALTERNATIF MASA DEPAN }\end{array}$ \\
\hline $\begin{array}{l}\text { - Nilai atau norma tidak berlaku } \\
\text { dalam sains hanya berlaku pada } \\
\text { pengguna sains. } \\
\text { - Kesadaran manusia } \\
\text { sepenuhnya merupakan derivat } \\
\text { dari faktor lingkungan dan } \\
\text { psikosomatik. } \\
\text { - Tidak mengenal adanya } \\
\text { kemutlakan kausalitas dan } \\
\text { prima causa. }\end{array}$ & $\begin{array}{l}\text { - Nilai atau norma inheren dalam } \\
\text { seluruh struktur sains, termasuk } \\
\text { pada pengguna sains. } \\
\text { - Kesadaran manusia memiliki dasar } \\
\text { apriori yang berisi iman, taqwa, dan } \\
\text { tauhid. } \\
\text { - Kemutlakan kausalitas merupakan } \\
\text { keharusan, dan Allah merupakan } \\
\text { kausa prima yang harus ditegakkan } \\
\text { dalam pemikiran ilmiah. }\end{array}$ \\
\hline
\end{tabular}

Ilustrasi di atas menunjukkan bahwa seharusnya pendidikan Islam mulai berusaha memberikan tawaran baru tentang sistem dan strategi pendidikan yang harus menempatkan ilmu naqliyah sebagai pokok pijakan pembinaan mental, intelektual, moral, etos kerja, dan spiritual. Pendidikan Islam tidak hanya memberikan justifikasi atas perkembangan ilmu-ilmu aqliyah dengan ilmu-ilmu naqliyah semata, tetapi harus menyusun suatu kurikulum yang tidak sekadar mencampur aduk kedua macam ilmu tersebut menjadi satu paket, tetapi harus menjadikan suatu sintesa yang mengintegrasikan keduanya menjadi satu kesatuan paradigma keilmuan.

\section{Catatan Akhir}

Menurut hemat saya, manusia dengan karakteristik berakhlak mulia dalam konteks makro dan mikro adalah bila pendidikan Islam yang dikembangkan mampu membentuk pribadi-pribadi yang amanah, cermat, ulet, adil, motivasi, berprestasi tinggi, menghargai waktu, hemat, berorientasi pada kualits, disiplin, jujur, demokratis, kesediaan untuk berbagi, istiqamah, dan cerdas. Pendidikan Islam dapat mencetak para lulusan yang anggun secara moral-spiritual dan juga tangguh secara 
intelektual. Bila itu menjadi kesepakatan semua pihak, maka titik tekan pendidikan bukan lagi pada transfer of knowledge and transfer of book karena peningkatan kemampuan tersebut tidak mungkin dicapai manakala "spiritualitas" didekati sebagai "pengajaran" (learning) semata. Seyogyanya, proses pembentukan kekuatan spiritualitas dalam pendidikan, hanya dapat dilakukan melalui proses pendidikan.

Bentuk pendidikan seperti apa yang relevan dengan upaya pembentukan spiritualitas dalam pendidikan? Saya tidak begitu setuju bila jawaban atas pertanyaan itu berbentuk penunjukkan suatu mata pelajaran tertentu, misalnya dengan cara membuat atau merumuskan kurikulum baru seperti agama, kewirausahaan, dan ilmu-ilmu penegetahuan lain. Ketidaksetujuan saya didasari oleh dua hal; pertama, lembaga pendidikan sebagaimana diatur dalam perundang-undangan bidang pendidikan, bukan semata untuk menyajikan pengetahuan tetapi lebih diarahkan sebagai jembatan yang mampu mengembangkan karakteristik kepribadian manusia Indonesia. Kemampuan berpikir lebih diutamakan ketimbang pengetahuan teknis. Kedua, pendidikan spiritualitas dalam pendidikan bukan semata wadah, namun lebih bersifat pada isi (content). Penanaman spiritualitas dalam pendidikan secara lebih komprehensif memang potensial melalui sistem pengajaran, namun masalahnya isi bahan ajar selain tidak menunjang pencapaian tujuan belajar, juga secara ideologis masih perlu diperdebatkan.

Dalam konteks pendidikan spiritualitas, pendidikan Islam perlu ditandai dengan kemampuan melakukan hubungan timbal balik secara sehat, antara peserta didik dengan lingkungan besar di luar dirinya, yaitu "Tuhan Yang Maha Kuasa", di samping kemampuannya berhubungan timbal balik secara sehat dengan dirinya sendiri dan orang lain. Landasan utama dari proses pendidikan ini adalah kualitas keimanan dan ketakwaan terhadap Tuhan Yang Maha Esa. Dari proses tersebut diharapkan muncul perilaku yang didasari oleh timbangan-timbangan spiritual yang 
berakar pada nilai-nilai keimanan dan ketaqwaan terhadap Tuhan Yang Maha Esa. Pada tingkatan ini akan tercemin nilai-nilai moralitas normatif-religius.

Dalam menghadapi berbagai situasi (terutama situasi krisis) yang mendera, pebelajar yang nalarnya dilandasi oleh kecerdasan spiritual, akan mampu mengendalikan dirinya dan menjaga keseimbangan dengan lingkungan atas dasar keyakinan spiritual yang kuat terhadap kuasa Allah Swt. Semua pikiran, sikap, dan tindakannya mencerminkan kondisi kepribadian yang sehat, sehingga memberikan makna yang sangat luas bagi diri dan umat di sekitarnya. $\bullet$

\section{Daftar Pustaka}

Abdurrahman An-Nahlawy, Pendidikan Islam di Rumah, Sekolah, dan Masyarakat, ter. Shihabuddin (Jakarta: Gema Insani Press, 1995).

Akbar S. Ahmed, Postmodernisme and Islam, ter. Muhammad Siroji (Bandung: Mizan, Bandung, 1997).

A. Malik Fajar, Menyiasati Kebutuban Masyarakat Modern Terhadap Pendidikan Luar Sekolah, makalah Seminar dan Lokakarya Pengembangan Pendidikan Islam Menyongsong Abad 21, IAIN, Cirebon, Tanggal 31 Agustus s/d 1 Sepetember, 1995. Azyumardi Azra, Esei-esei Intelektual Muslim dan Pendidikan Islam (Jakarta: Logos Wacana Ilmu, 1998). , Pendidikan Islam (Jakarta: Logos, 1999).

Djamaludin Ancok, Membangun Kompetensi Manusia dalam Milenium Ketiga, dalam Psikologika, Jurnal Pemikiran dan Penelitian Psikologi, no. 6 Tahun III, UII, 1998.

Endang Saifuddin Anshari, Wawasan Islam: Pokok-pokok Pikiran tentang Islam dan Umatnya (Bandung: Pustaka Salman,1982).

Fachry Ali, Agama, Islam dan Pembangunan (Yogyakarta: PLP2M,1985). 
, Islam, Ideologi Dunia dan Dominasi Struktural

Bandung: Mizan, Bandung, 1985).

Fazlur Rahman, Islam and Modernity: Transformation of an Intellectual Tradition (Chicago: The University of Chicago, 1982).

H.A.R. Tilaar, Beberapa Agenda Reformasi Pendidikan dalam Perspektif Abad 21 (Magelang: Tera Indonesia, 1998).

Hidayat Nata Atmaja, Karsa Menegakekan Jiwa Agama dalam Dunia Ilmiah versi Ihya Ulumuddin (Bandung: Iqra', 2000). , Krisis Global Ilmu Pengetahuan dan Penyembubannya, seri Psy-War no. 001/82 (Bandung: Iqra', 1982).

M. Amien Rais, Dinamika Pemikiran Islam dan Mubammadiyah (Yogyakarta: Lembaga Pustaka dan Dokumentasi Pimpinan Pusat Muhammadiyah, 1996).

M. Dawam Rahardjo, Keluar dari Kemelut Pendidikan Nasional Menjawab Tantangan Kualitas Sumber Daya Manusia Abad 21 (Jakarta: PT Intermasa, 1997).

M. Irsyad Sudiro, Pendidikan Agama dalam Masyarakat Modern, makalah, dalam Seminar dan Lokakarya Nasional Revitalisasi Pendidikan Agama Luar Sekolah dalam Masyarakat Modern, Cirebon, Tanggal 30-31 Agustus, 1995.

Miska Muhammad Amien, Epistemologi Islam (Jakarta: UI Pres, 1983).

Muhammad Idrus, "Menggugat Proses Belajar Mengajar di Perguruan Tinggi", Jurnal Mukaddimah (Yogyakarta: Kopertais Wilayah III PTAIS DIY, 2001).

Muslih Usa, Pendidikan Islam dalam Peradaban Industrial (Yogyakarta: Aditya Media, 1997). , Pendidikan Islam di Indonesia Antara Cita dan Fakta (Yogyakarta: Tiara Wacana, 1991).

Nurcholish Madjid, Islam dan Doktrin Peradaban (Jakarta: Paramadina, 1996).

Nurul Huda dkk., Paradigma Pendidikan Islam (Pustaka Pelajar: Yogyakarta, 2001). 
Raymond Toruan, Globalisasi: Dunia Makin Panas dalam Menuju Masyarakat Baru Indonesia, Antisipasi terhadap Tantangan Abad XXI (Jakarta: Gramedia, 1990).

Richard Crowford, In the Era of Human Capital (New York: Harper Bussines, 1991).

Roehan Anwar, "Prinsip-prinsip Pendidikan Islam Versi Mursi", dalam Jurnal Pendidikan Islam IAIN Sunan Kalijaga, vol. 1, Yogyakarta, 1991.

Syamsul Arifin, Spiritualisasi Islam dan Peradaban Masa Depan (Yogyakarta: SIPRES, 1996).

Syed Sajjad Husain dan Syed Ali Ashraf, Krisis Pendidikean Islam, ter. Rahmani Astuti (Bandung: Risalah, 1986).

Yaya M. Abdul Aziz (ed.), Visi Global: Antisipasi Indonesia Memasuki Abad ke XXI (Yogyakarta: Pustaka Pelajar, 1998).

Yusuf Amir Feisal, Reorientasi Pendidikan Islam (Jakarta: Gema Insani Press, 1996).

Zaini Dahlan, Qur'an Karim dan Terjemahannya (Yogyakarta: UII Press, 1998).

Zakiyah dkk., Ilmu Pendidikan Islam (Jakarta: Bumi Aksara, 1996). 